\title{
Simulated impacts of rainfall extremes on yield responses of various barley varieties in a temperate region**
}

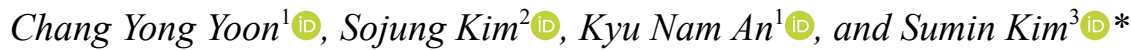 \\ ${ }^{1}$ Crop Research Division, Jeollanamdo Agricultural Research and Extension Services, Naju-si, Jeollanam-do 58123, Korea \\ ${ }^{2}$ Department of Industrial and Systems Engineering, Dongguk University-Seoul, Seoul 04620, Korea \\ ${ }^{3}$ Department of Environmental Horticulture and Landscape Architecture, College of Life Science and Biotechnology, \\ Dankook University, Cheonan-si, Chungnam 31116, Korea
}

Received December 18, 2020; accepted March 8, 2021

\begin{abstract}
As population rises, more people need to be fed. With increasing income, the potential exists for increases in the demand for cereals (i.e., barley). Since barley has a high level of tolerance to environmental stressors, this crop has been recommended as a potential crop for food security in marginal environments. In this study, a crop growth Agricultural Land Management Alternatives with Numerical Assessment Criteria model, was parameterized and used to simulate the yields of two barley types grown in a temperate environment at a latitude of $35^{\circ} \mathrm{N}$. In order to apply this crop model to barley, 19 years of field data were used to model calibration and validation. As a result, the ALMANAC model accurately simulated yields for both barley types. The validated model was used to predict yields under three diverse seasonal rainfall scenarios associated with different patterns of the Central Pacific El Niño influence. According to the simulation results, excessively high seasonal rainfall decreased barley yields. Crop price and annual revenue of the two barley types were also evaluated using a non-linear regression model. For the malt type, the food price was higher with a higher rainfall, while naked barley had a higher revenue under the conditions of a lower rainfall.
\end{abstract}

Keywords: barley, rainfall, simulation, food cost, grain yield

\section{INTRODUCTION}

Barley (Hordeum vulgare) has been an important temperate cereal crop worldwide for 10000 years. This crop is the 4th most important cultivated cereal in the world,

*Corresponding author e-mail: sumin.kim@dankook.ac.kr

**This work was supported by KEPCO Research Institute and by the Dongguk University Research Fund of 2020. following wheat (genus species), rice (genus species), and maize (genus species). Although barley is an important food crop, it is also used for the production of alcoholic drinks, but despite its versatility global barley demand has been decreasing continuously in recent years (Newton et al., 2011). In South Korea, barley production has been continuously decreasing since 2009 (FAO, 2020) due to decreased consumption and profitability (USDA-FAS, 2019). However, as food choices and eating habits have started to become healthier, demands for barley have been increasing slowly (USDA-FAS, 2019). Barley is a valuable source of food and forage that can provide fibre, vitamins, and minerals essential for humans and supply additional energy and protein for animals. In addition, since barley has a higher abiotic stress tolerance than other crops (Munns et al., 2008; Baik et al., 2011; Neyo et al., 2012), this crop has been recommended as a promising crop for food security in marginal environments (Newton et al., 2011). This also presents the possibility of extending its future production to areas suffering from climate change, which poses a threat to sustainable crop production worldwide. Due to climate change, temperature and rainfall patterns have been altered. For example, in 2019, an unusually warm and wet winter was observed in Korea (KMA, 2020). These changes may increase or decrease crop yields depending on the location where the crop is grown.

(C) 2021 Institute of Agrophysics, Polish Academy of Sciences (c) (1) () $\odot$ 
Forecasting the crop yield variations of a major crop such as barley may play an important role in estimating the future impact of climate change. For example, the accurate prediction of the impact of climate change on agriculture may provide useful information for societies to develop a better response to food production shortages and food price increases caused by extreme weather. Various crop growth models have been used to evaluate the potential impact of climate change on crop yield. Takác and Šiška (2009) used an agroecological model, DAISY, to simulate the yield of spring barley on the Danubian lowland in Slovakia. Other studies used CERES-Barley to simulate the impact of climate change on barley yields in various locations of South Korea (Ko et al., 2019) and in the Mediterranean basin (Cammarano et al., 2019). Although both of the studies of Ko et al. (2019) and Cammarano et al. (2019) projected incremental changes in temperature in the study regions, they reported different yield patterns. Ko et al. (2019) reported that yields would increase in the future while Cammaron et al. (2019) predicted that yields would decrease by $8-25 \%$ depending on climate projection. Cammaron et al. (2019) also reported that barley yields were substantially affected by rainfall and soil moisture content as more yield variation was observed in wet conditions. Based on comparisons between simulation results, crop yields are also significantly affected by soil properties and climate projections that can vary depending on the climate model being used. Therefore, new results may be found in different locations and under different climate scenarios. This suggests that more evaluations using data from different locations and climate scenarios are required in order to obtain accurate impacts of climate change on barley production.

In the present study, the Agricultural Land Management Alternatives with Numerical Assessment Criteria (ALMANAC) model was used to predict the growth and development of barley. This model is a field-scale crop growth model that can simulate plant growth, water balance, soil erosion, soil organic carbon, and nutrient (nitrogen and phosphorous) cycling on a daily time step. The ALMANAC model is well designed to simulate complex plant rotations and fallow-cropping systems. It is useful for the evaluation of the impact of a wide variety of environmental and management on forage (e.g. barley) production. Debeake et al. (1997) used ALMANAC to demonstrate the diverse cropping systems associated with controlling weed growth in plots where various winter and spring wheat genotypes are grown. This model has been used to evaluate crop growth adaptations under different environmental conditions (Kim et al., 2017) and different climate change scenarios (Behrman et al., 2014; Kim et al., 2020). Thus, ALMANAC simulations can help farmers to determine the best cropping management practices to help them to effectively adapt to frequent extreme weather events. The model version developed in this study represents the first time that ALMANAC has simulated barley growth in the Asian region.

The aim of this study is to develop the barley growth model to predict the barley grain yield and economic value under different rainfall scenarios in South Korea. The simulation information will provide a useful guide concerning the impact of different rainfall events on barley yield. In order to improve the accuracy of the model, nineteen years of the yield data of various barley varieties were used to improve the crop growth model. In addition to yield data, morphological characteristics including height, length of inflorescence, and the number of grains per plant for each barley variety were investigated. In this study, the relationships between the various morphological characteristics, yield, and weather variables (e.g. temperature and precipitation) were analysed in order to study the influences of both morphological and weather variables on crop yield. The Meteorological Administration of Korea projected that incidents of extreme weather events such as heat waves, heavy snow, cold waves, drought, and heavy rain would increase in South Korea (KMA, 2014) and emphasized the importance of developing a climate model system that could project extreme climatic events so that the accuracy of crop yield prediction could be increased. In this study, based on the results of correlations between barley yields and weather variables, the impact of changes to significant weather factors on barley yield were tested. The 19 years of yield data collected were used for the calibration and validation of the ALMANAC model. This increased the level of confidence in the ALMANAC model for forecasting barley yields in diverse weather conditions (e.g., precipitation). A non-linear regression model was then used to evaluate the unit price (or revenue) of the harvested yields for various barley types under diverse rainfall scenarios.

\section{MATERIALS AND METHODS}

The field experiment was conducted at Jeollanam-do Agricultural Research and Extension Center in Jeollanamdo province, South Korea during the growing seasons from autumn in 2000 to spring in $2019\left(35^{\circ} 1^{\prime} 19.35^{\circ} \mathrm{N}\right.$, $\left.126^{\circ} 38^{\prime} 29.65^{\circ} \mathrm{E}\right)$. Jeollanam-do has temperate weather conditions and has been projected to produce the most barley in South Korea in 2020. This province produced $63000 \mathrm{Mg}$ of barley, which accounts for $44 \%$ of the total barley production in South Korea (Statistics Korea, 2020b). Naju-si was selected as the location of the study because agriculture is an important industry in this area as shown by the fact that almost one fourth of the population ( $24 \%$ of the total population of Naju-si) is engaged in agricultural activities (Naju-si, 2020). Thus, simulating barley production in this area will provide a better understanding of the impact of rainfall change on barley production in Jeollanam-do in South Korea. 
According to the National Institute of Agricultural Science, RDA (Available online at http://soil.rda.go.kr/ soil/soilmap/characteristic.jsp), the soil type in the study location is Tongcheon (Tc, loam). The plots were arranged according to a randomized completed block design with three replicates. The treatments included six barley varieties (three naked and three malt barley varieties). For the naked varieties, Saessal, Saechalssal and Huinchalssal were used. Dusan 29ho, Jinyang, and Hopum were the malt barley varieties. The naked varieties were named sixrow barleys, while the malt varieties were named two-row barleys.

In each year, more than one variety of each barley type (either naked or malt) was tested. The size of the subplot was $1.5 \times 6 \mathrm{~m}=9 \mathrm{~m}^{2}$. Barley tolerates low temperatures. Korean farmers usually plant barley in the autumn and begin to harvest in spring. Seeds of both the naked and malt types were row planted at $25 \mathrm{~cm}$ row spacing at rates of 150 and $160 \mathrm{~kg} \mathrm{ha}^{-1}$, respectively, around October 25th. In early February, compost organic material was applied to the field at a rate of $250 \mathrm{~kg} \mathrm{ha}^{-1}$. In late May, all barley varieties were harvested. At harvest time, the plant height, length of inflorescence, number of tillers per $\mathrm{m}^{2}$, number of florets per tiller, and oven dry $\left(65^{\circ} \mathrm{C}\right)$ grain yield $\left(\mathrm{kg} \mathrm{ha}^{-1}\right)$ were measured. The plant height was the length from ground level to the bottom of the plant's inflorescence. The length of inflorescence was the length from the bottom to the top of the plant's inflorescence. Daily weather data including the average maximum and minimum temperatures, total precipitation, and average wind speed for the study location were collected from the nearest weather station $(\mathrm{NaJu} 710)$.

The relationships between the seasonal weather varieties (October-May) and morphological characteristics were analysed. A statistical analysis (ANOVA) was conducted using Proc GLM to test the significant differences in grain yields between the three barley varieties within each barley type. Statistical Analysis Software version 9.3 (SAS Institute, NC, USA) was used to test the statistical analysis. Since the morphological characteristics of all three varieties for each barley type were not evaluated for the same year, years that had similar weather conditions were selected to compare grain yields for each barley type. For malt barley types, the grain yields collected in 2000-2007 for Dusan 29ho and Jinyang and in 2005-2011 and 2016 for Hopum were used. For naked barley types, the grain yields collected in 2012-2018 for Saechalssal and Huinchalssal and 2001-2008 for Saessal were used. The morphological characteristics of each barley type and the seasonal weather data (2000-2018) were correlated using Pearson's correlation analysis.

The ALMANAC model is a single field-based processlevel simulator, which can be used to accurately simulate the growth, development, and grain yield of crops influenced by weather conditions. In the simulation, in order to determine the effects of weather conditions on grain yields, barley grain crops were only produced in rainfed areas. To improve the stability and accuracy of the crop growth simulation, high-quality input data for weather, soil, and management are required (Grassini et al., 2015). Detailed soil information was obtained from the National Institute of Agricultural Science, RDA (Available online at http://soil. rda.go.kr/soil/soilmap/characteristic.jsp). The values for several soil components, including the organic matter content $\left(\mathrm{g} \mathrm{kg}^{-1}\right)$, phosphorus concentration $\left(\mathrm{mg} \mathrm{kg}^{-1}\right)$, cation exchange capacity $\left(\mathrm{cmol} \mathrm{kg}^{-1}\right)$, and the $\mathrm{pH}$ in top soil $(0-20 \mathrm{~cm})$ are listed in Table 1.

ALMANAC incorporates a number of equations that describe how the parameters interact with other parameters in the model. Plant parameters were estimated based on 1) leaf-area development, 2) development-rate response to temperature, 3) radiation-use efficiency and physical descriptions, and 4) nitrogen and phosphorous concentrations in plant biomass. This model simulates the light competition between plants using light fraction interception by the canopy which may be calculated by using Beer's law (Monsi et al., 1953), the light extinction coefficient ( $k$ ), and leaf area index $(L A I)$ :

$$
\text { fraction }=1.0-e^{(-k L A I)} \text {. }
$$

The plant parameter values were derived from the previous study (Kiniry et al., 1995), field data, and the database of the ALMANAC model, with minimal adjustment after comparing the output with the measured barley yields.

Table 1. Soil properties (soil organic matter content, phosphorous concentration, cation exchange capacity, and $\mathrm{pH}$ ) in top soil $(0-20 \mathrm{~cm})$ and weather variables (average maximum temperature, average minimum temperature, total precipitation, average wind speed) during barley growing seasons (October-May) in 2000-2019 at the study location in Jeollanam-do, South Korea

\begin{tabular}{lcccc}
\hline Study & \multicolumn{4}{c}{ Soil properties } \\
\hline Location & $\mathrm{OM}\left(\mathrm{g} \mathrm{kg}^{-1}\right)$ & $\mathrm{P}\left(\mathrm{mg} \mathrm{kg}^{-1}\right)$ & $\mathrm{CEC}\left(\mathrm{cmol} \mathrm{kg}^{-1}\right)$ & $\mathrm{pH}$ \\
\hline & 26 & 159 & 7.3 & 5 \\
$35^{\circ} 1^{\prime} 19.35^{\circ} \mathrm{N}, 126^{\circ} 38^{\prime} 29.65^{\circ} \mathrm{E}$ & & Weather variable (October -May) & \\
& Max. temp. $\left({ }^{\circ} \mathrm{C}\right)$ & Min. temp. $\left({ }^{\circ} \mathrm{C}\right)$ & Total prec. $(\mathrm{mm})$ & Avg. wind $\left(\mathrm{m} \mathrm{s}^{-1}\right)$ \\
& 14.88 & 2.58 & 509 & 1.62 \\
\hline
\end{tabular}


According to a statistical analysis, in general, there were no significant differences in grain yields between the varieties used within each type (Table 2). However, there was a significant $(p=0.04)$ difference in grain yield between the two barley types (Table 2). Thus, in the ALAMANC plant database, two sets of plant parameters, namely NBAR and BBAR, were created for the naked and malt barley types, respectively. During calibration, most of the plant parameters were determined based on field data (plant height and plant density) and also values reported in a previous study. Kiniry et al. (1995) developed plant parameters for spring barley. Several key plant growth parameters such as DMLA, DLAP1, DLAP2, DLAI, RLAD, TG, TB, PHU, FRST1, and FRST2 were derived from Kiniry et al. (1995). The

Table 2. Grain yields of naked barley varieties (Huinchalssal, Saechalssal, and Seassal) and malt barley varieties (Dusan 29ho, Jinyang, and Hopum) averaged over different years

\begin{tabular}{llcc}
\hline \multirow{2}{*}{ Variety } & \multicolumn{3}{c}{ Average } \\
\cline { 2 - 4 } & Years & $\begin{array}{c}\text { Grain yield } \\
\left(\mathrm{Mg} \mathrm{ha}^{-1}\right)\end{array}$ & $\mathrm{SD}$ \\
\hline Huinchalssal & $2012-2018$ & 3.77 & 0.80 \\
Saechalssal & $2012-2018$ & 3.68 & 0.78 \\
Seassal & $2001-2008$ & 3.48 & 0.29 \\
& p-value & 0.61 & \\
Dusan 29ho & $2000-2007$ & 3.89 & 0.59 \\
Jinyang & $2000-2007$ & 3.89 & 0.59 \\
Hopum & $2005-2011,2016$ & 3.83 & 0.62 \\
& p-value & 0.91 & \\
Type & & & 0.55 \\
Naked & 2000-2018 & 3.65 & 0.64 \\
Malt & $2000-2018$ & 3.93 & \\
& p-value & 0.04 & \\
\hline
\end{tabular}

Grain yields of two barley types were averaged over 2000-2019. A statistical analysis (ANOVA) was used to compare yields among the varieties for each barley type (naked and malt) and between the two types of barley (naked and malt) $(\alpha=0.05)$. same values for these parameters were used for both naked and malt barley types. The value of DMLA, a potential leaf area index, was 5 . The pattern of the leaf area development curve prior to anthesis is described by the values of DLAP1 and DLAP2. DLAP1 and DLAP2 had values of 15.01 and 45.95 , respectively. The value of DLAI, for the portion of the season when maximum LAI occurred and when LAI began to decrease, was 0.6. The value of RLAD, the shape of the LAI curve after DLAI was reached, was 1 . TG was the base temperature and TB was the optimum temperature for growing degree-day calculation. The values of TG and TB were 0 and $25^{\circ} \mathrm{C}$, respectively. PHU was the growing degree-days from planting to maturity. Its value was 1570 . FRST1 and FRST2 represented how biomass was lost as a result of frost damage. Their values were 15.001 and 15.01 , respectively.

The maximum plant heights were derived from the sum of the plant height and length of inflorescence for each type. The maximum heights (HMX) for naked and malt barley types were $0.93 \mathrm{~m}$ and $0.94 \mathrm{~m}$, respectively. The values of maximum height were the highest measured heights from the field study. The value of radiation use efficiency (WA) was 40 for both barley types. The values of WA were adjusted through model calibration. According to morphological field analysis, malt barley had fewer florets per inflorescence and a higher biomass than naked barley (Table 3). This means that malt barley might have a higher value for harvest index (HI) (i.e., the dry matter of seed yield divided by the total above ground biomass at maturity). The value of $\mathrm{HI}$ for naked barley was 0.54 , which was the same value reported by Kiniry et al. (1995). The value of HI for malt barley was 0.6 .

For calibrating ALMANAC, the measured grain yields collected from 2001 to 2009 were compared with the simulated yields. In order to validate ALMANAC, the measured grain yields collected from 2010 to 2018 were compared to the simulated yields. The measured yields used for comparison were the average yield values of all three varieties within each barley type. The measured yields averaged for Saessal, Saechalssal, and Huinchalssal were used for naked barley to serve as a comparison with the simulated yields while the average yields of Dusan 29ho, Jinyang, and Hopum were used for the malt barley type. In order to test

Table 3. Mean values and standard deviations of height, length of inflorescence, number of tillers, and number of florets of naked and malt barley types in 2000-2019

\begin{tabular}{|c|c|c|c|c|c|c|c|c|}
\hline Types & $\begin{array}{l}\text { Height } \\
\text { (cm) }\end{array}$ & SD & $\begin{array}{l}\text { Length of } \\
\text { inflorescence } \\
(\mathrm{cm})\end{array}$ & SD & $\begin{array}{l}\text { No. } \\
\text { tillers }\end{array}$ & $\mathrm{SD}$ & $\begin{array}{l}\text { No. } \\
\text { florets }\end{array}$ & SD \\
\hline Naked & 74.45 & 9.69 & 4.98 & 0.56 & 675 & 103 & 57 & 6.61 \\
\hline Malt & 76.67 & 7.45 & 6.46 & 0.73 & 859 & 125 & 24 & 2 \\
\hline
\end{tabular}


model accuracy, the root-mean square error (RMSE), mean bias error $(M B E)$, and mean absolute error $(M A E)$ were calculated (Eqs (2) - (4), respectively):

$$
\begin{gathered}
\text { RMSE }=\sqrt{\frac{\sum_{i=1}^{n}\left(O_{i}-S_{i}\right)^{2}}{n},} \\
M B E=\frac{\sum_{i=1}^{n}\left(S_{i}-O_{i}\right)}{n},
\end{gathered}
$$

and

$$
M A E=\frac{\sum_{i=1}^{n}\left|S_{i}-O_{i}\right|}{n},
$$

where: $i$ was the $i$ th observation, $n$ was the total number of observations, $S_{i}$ was the $i$ th simulated value, and $O_{i}$ was the $i$ th observed value.

According to Druille et al. (2020), both RMSE and MAE could be used to evaluate the ALMANAC model prediction error in units of the variable of interest. These metrics were in the range from 0 to $\infty$. They were unaffected by the direction of the errors. Lower values of these metrics indicated an improved model performance. Mean bias error was used to test whether the model generated an overestimation (positive values) or an underestimation (negative values) of the simulated yields.

According to the correlation analysis between barley grain yield and weather variables, seasonal rainfall moderately influenced barley grain yield. Kim et al. (2017) studied seasonal rainfall changes in Korea which are closely associated with the different evolution patterns of the Central Pacific (CP) El Niño influence. Three seasonal rainfall patterns, including prolonged decay (warm sea surface temperature (SST) generated in the equatorial Pacific region), abrupt decay (abnormal SST rapid decline), and symmetrical decay patterns (an increase in the SST occurring in $\mathrm{CP}$ ), were studied. More detailed information may be found in the study of Kim et al. (2017). According to the results of the present study, the Korean Peninsula experienced an overall increasing pattern in spring rainfall during both prolonged decay years and symmetrical decay years. The amount of spring rainfall for the study area increased by up to $20 \%$ during the prolonged decay years, while spring rainfall increased up to $40 \%$ during the symmetrical decay years. Unlike the other two patterns, the amount of spring rainfall decreased by $10 \%$ during the abrupt decay years.

In the present study, we investigated changes in the grain yields of two barley types (naked and malt) under three different rainfall patterns (prolonged decay, abrupt decay, and symmetrical decay). The total precipitation for the simulations were increased by $20 \%$ during the historical years (2000-2019) with a prolong decay pattern, decreased by $10 \%$ with an abrupt decay pattern, and increased by $40 \%$ with a symmetrical decay pattern. The successfully validated ALMANAC model was used to simulate the grain yields of naked and malt barley types under three different rainfall patterns. We assumed that the temperature and $\mathrm{CO}_{2}$ levels remained unchanged from the historical years (2000-2019).

The unit price (or unit revenue) of the harvested yield was estimated via the non-linear economic model shown in Eq. (5):

$$
y=a x^{-b},
$$

where: $y$ is the unit price $\left(\$ \mathrm{Mg}^{-1}\right), x$ is the grain yield $\left(\mathrm{Mg} \mathrm{ha}{ }^{-1}\right)$, and $\mathrm{a}$ and $\mathrm{b}$ are constants. Generally, the unit price of grain such as rice and barley had a non-linear relationship with its harvest yield (Carter, 1994; Eissa and Refai, 2019; Barboza, 2020). In Eq. (5), the unit price (y) decreased as the production yield increased $(x)$. This appropriately reflects the reality. Because of the law of scarcity, if grain is overproduced, it is likely to be thrown away (Khush, 1987). Since each person only needs a certain amount of food to live, overproduced grain has no value. Equation (5) is calibrated by the least square method, which estimates parameters (or constants) in order to minimize the estimation error of a given model (Kim et al., 2020). Based on the calibrated model, we could identify which scenario would be the best in terms of potential unit revenue.

\section{RESULTS AND DISCUSSION}

According to the statistical analysis, there were no significant variations between varieties within the barley type (Table 2). For the naked barley type, measured dry grain yields of Huinchalssal, Saechalssal, and Seassal were 3.77, 3.68 , and $3.48 \mathrm{Mg} \mathrm{ha}^{-1}$, respectively. The measured dry grain yields of Dusan 29ho, Jinyan, and Hopum for malt barley were $3.89,3.89$, and $3.83 \mathrm{Mg} \mathrm{ha}^{-1}$, respectively. The measured dry grain yields averaged for all malt barley types in 2000-2018 were significantly higher than those of the naked barley type $(p=0.04)$. The average grain yield was $3.93 \mathrm{Mg} \mathrm{ha}^{-1}$ for the malt barley type and $3.65 \mathrm{Mg} \mathrm{ha}^{-1}$ for the naked barley type.

Compared to the naked barley type, the malt barley type had a greater height, length of inflorescence, and number of tillers (Table 3). The height was $74.5 \mathrm{~cm}$ for the naked barley and $76.7 \mathrm{~cm}$ for malt barley. The length of inflorescence of the malt barley type was $6.5 \mathrm{~cm}$, while the length of inflorescence of the naked barley type was $5.0 \mathrm{~cm}$. The numbers of tillers per $\mathrm{m}^{2}$ of naked and malt types were 675 and 859 , respectively. The higher number of tillers for the malt barley type may result in higher grain yields. Unlike other morphological parameters, the number of florets per inflorescence of the naked type was higher than that of the malt type (Table 2).

Correlations between the morphological variables were tested for both the naked and malt barley types (Table 4). The number of tillers was positively and moderately correlated with height for both barley types $(\mathrm{R}=0.55$, $\mathrm{p}<0.0001$ for the naked type and $\mathrm{R}=0.57, \mathrm{p}<0.0001$ for the malt type). For both barley types, there were positive 
Table 4. Correlations between morphological variables and between morphological variables and weather variables for naked and malt barley types

\begin{tabular}{|c|c|c|c|c|c|c|}
\hline \multicolumn{2}{|c|}{ Variables } & Height & $\begin{array}{l}\text { Length of } \\
\text { inflorescence }\end{array}$ & No. tillers & No. florets & Grain yield \\
\hline \multicolumn{7}{|c|}{ Naked barley } \\
\hline \multirow{4}{*}{ Morphological variables } & $\mathrm{H}$ & 1 & & & & \\
\hline & LF & $0.35^{*}$ & 1 & & & \\
\hline & $\mathrm{T}$ & $0.55 * * *$ & $0.58 * * *$ & 1 & & \\
\hline & $\mathrm{F}$ & 0.12 & $0.65 * * *$ & 0.26 & 1 & \\
\hline \multirow{5}{*}{ Weather variables } & GY & $0.32 *$ & 0.02 & 0.30 & 0.21 & 1 \\
\hline & $\operatorname{Max} T$ & 0.05 & $0.34 *$ & 0.17 & 0.17 & -0.14 \\
\hline & $\operatorname{Min} T$ & -0.14 & 0.04 & 0.04 & 0.12 & -0.12 \\
\hline & Prep & -0.04 & -0.13 & -0.06 & 0.00 & $0.55 * * *$ \\
\hline & Wind & $-0.42 * *$ & $-0.67 * * *$ & $-0.49 * *$ & $-0.37 * *$ & 0.09 \\
\hline \multicolumn{7}{|c|}{ Malt barley } \\
\hline \multirow{5}{*}{ Morphological variables } & $\mathrm{H}$ & 1.00 & & & & \\
\hline & LF & 0.16 & 1.00 & & & \\
\hline & $\mathrm{T}$ & $0.57 * * *$ & 0.05 & 1.00 & & \\
\hline & $\mathrm{F}$ & 0.08 & $0.71 * * *$ & -0.06 & 1.00 & \\
\hline & GY & 0.31 & -0.20 & $0.62 * * *$ & 0.01 & 1.00 \\
\hline \multirow{4}{*}{ Weather variables } & $\operatorname{Max} T$ & $-0.42 *$ & 0.24 & -0.31 & 0.34 & -0.10 \\
\hline & Min T & $-0.47 * *$ & 0.16 & $-0.61 * * *$ & 0.19 & -0.27 \\
\hline & Prep & 0.31 & -0.39 & 0.30 & -0.19 & $0.40 *$ \\
\hline & Wind & 0.11 & $-0.60 * * *$ & 0.01 & $\mathbf{- 0 . 5 9} * * *$ & -0.12 \\
\hline
\end{tabular}

Correlation significant - numbers in bold. Correlation coefficients between 0.5 and 0.7 indicated moderate correlations between variables, while correlation coefficients between 0.3 and 0.5 indicated variables with weak correlations. H - height, LF - length of inflorescence, T - number of tillers, F - number of florets, GY - dry grain yield, Prep - total precipitation (October-May). Correlation is significant at the: $* 0.05, * * 0.01, * * * 0.0001$ levels.

and moderate correlations between the number of florets and the length of inflorescence $(\mathrm{R}=0.65, \mathrm{p}<0.0001$ for the naked type and $\mathrm{R}=0.71, \mathrm{p}<0.0001$ for the malt type). The number of tillers was moderately and positively correlated with the grain yield of the malt type $(\mathrm{R}=0.62, \mathrm{p}<0.0001)$. However, it only showed a weak correlation with the grain yield of the naked type $(\mathrm{R}=0.3$, n.s.) (Table 4$)$. This may be why the malt barley type had a higher grain yield than the naked barley type (Table 3 ).

Correlations between the morphological variables and the seasonal weather variables were analysed for both the naked and malt barley types (Table 4). For both the naked and malt barley types, wind speed was moderately and negatively correlated with the length of inflorescence ( $\mathrm{R}=-0.67, \mathrm{p}<0.0001$ for the naked barley and $\mathrm{R}=-0.6$, $\mathrm{p}<0.0001$ for the malt barley type). The total seasonal precipitation was positively and moderately correlated with the grain yield of the naked barley type $(\mathrm{R}=0.55, \mathrm{p}<0.0001)$. For malt barley, the minimum temperature was negatively correlated with the number of tillers per $\mathrm{m}^{2}$. Wind speed was negatively and moderately correlated with the number of florets per tiller for the malt barley type. Seasonal total precipitation had a weak and positive correlation with the grain yield of the malt barley type $(\mathrm{R}=0.4, \mathrm{p}<0.05)$.

Since there were no significant differences in the barley variables within each barley type, two barley plant parameters were created: naked and malt barley types (Table 5). For model calibrations, measured grain yields for 20012009 were compared with the simulated grain yields for both types. As shown in Table 6, the ALMANAC model was successfully calibrated for both types. The measured grain yields of both the naked and malt types averaged for 2001-2009 were 3.60 and 4.04 $\mathrm{Mg} \mathrm{ha}^{-1}$, respectively, while the simulated grain yields of both the naked and malt types were 3.62 and 4.03, respectively. The values of RMSE for both the naked and malt types were 0.33 and $0.45 \mathrm{Mg} \mathrm{ha}^{-1}$, respectively. The values of $M B E$ and $M A E$ for both types were very low, showing that the ALMANAC performance could be characterized as 'very good.'

For model validation, the measured grain yields for 2010-2018 were compared with the simulated yields for both barley types (Table 6). The measured grain yields of the naked and malt types were 3.73 and $3.76 \mathrm{Mg} \mathrm{ha}^{-1}$, 
Table 5. ALMANAC input parameters for naked (NBAR) and malt (BRAR) barley types

\begin{tabular}{|c|c|c|c|c|}
\hline \multirow{2}{*}{ Parameter } & \multirow{2}{*}{ Definition } & \multirow{2}{*}{$\begin{array}{l}\text { Naked } \\
\text { NBAR }\end{array}$} & & \multirow{2}{*}{$\begin{array}{c}\text { Malt } \\
\text { BRAR }\end{array}$} \\
\hline & & & & \\
\hline WA & Radiation use efficiency & & 40 & \\
\hline DMLA & Potential leaf area index & & 5 & \\
\hline DLAP1 & \multirow{2}{*}{ Two points on optimal (nonstress) leaf area development curve } & & 15.01 & \\
\hline DLAP2 & & & 45.95 & \\
\hline DLAI & $\begin{array}{l}\text { Fraction of the growing season in heat units in divided by the } \\
\text { total heat units accumulated between planting and crop maturity }\end{array}$ & & 0.6 & \\
\hline RLAD & Leaf-area-index decline rate parameter & & 1 & \\
\hline TG & Optimal growth temperature $\left({ }^{\circ} \mathrm{C}\right)$ & & 25 & \\
\hline $\mathrm{TB}$ & Base growth temperature $\left({ }^{\circ} \mathrm{C}\right)$ & & 0 & \\
\hline PHU & Potential heat unit & & 1570 & \\
\hline FRST1 & \multirow{2}{*}{ Two points on the frost damage curve } & & 5.001 & \\
\hline FRST2 & & & 15.01 & \\
\hline HMX & Maximum height (m) & 0.93 & & 0.94 \\
\hline $\mathrm{HI}$ & Harvest index & 0.54 & & 0.6 \\
\hline
\end{tabular}

Table 6. Summary of simulated and measured barley grain yields, standard deviations, root mean square error (RMSE), mean bias error $(M B E)$, and mean absolute error $(M A E)$ for ALMANAC model calibration and validation

\begin{tabular}{|c|c|c|c|c|c|c|c|c|}
\hline \multirow{3}{*}{ Barley type } & \multirow{3}{*}{ Year } & Average & \multirow{3}{*}{$\begin{array}{l}\text { Standard } \\
\text { deviation }\end{array}$} & Average & \multirow{3}{*}{$\begin{array}{l}\text { Standard } \\
\text { deviation }\end{array}$} & \multirow{2}{*}{$R M S E$} & \multirow{2}{*}{$M B E$} & \multirow{3}{*}{$M A E$} \\
\hline & & \multirow{2}{*}{$\begin{array}{l}\text { Measured grain } \\
\text { yields }\left(\mathrm{Mg} \mathrm{ha}^{-1}\right)\end{array}$} & & \multirow{2}{*}{$\begin{array}{l}\text { Simulated grain } \\
\text { yields }\left(\mathrm{Mg} \mathrm{ha}^{-1}\right)\end{array}$} & & & & \\
\hline & & & & & & & $\left(\mathrm{Mg} \mathrm{ha}^{-1}\right)$ & \\
\hline \multicolumn{9}{|c|}{ Calibration } \\
\hline Naked & 2001-2009 & 3.60 & 0.40 & 3.62 & 0.30 & 0.33 & 0.025 & 0.27 \\
\hline Malt & 2001-2009 & 4.04 & 0.65 & 4.03 & 0.33 & 0.45 & -0.006 & 0.38 \\
\hline \multicolumn{9}{|c|}{ Validation } \\
\hline Naked & 2010-2018 & 3.73 & 0.65 & 3.38 & 0.35 & 0.82 & -0.35 & 0.76 \\
\hline Malt & 2010-2018 & 3.76 & 0.76 & 3.75 & 0.39 & 0.87 & -0.01 & 0.69 \\
\hline
\end{tabular}

respectively. The simulated yields of the naked and malt types were 3.38 and $3.75 \mathrm{Mg} \mathrm{ha}^{-1}$, respectively. The $R M S E$ values of the naked and malt types were 0.82 and $0.87 \mathrm{Mg}$ $\mathrm{ha}^{-1}$, respectively. The $M A E$ values of the naked and malt types were 0.76 and $0.69 \mathrm{Mg} \mathrm{ha}^{-1}$, respectively. According to the results of $M B E$, the simulation for the naked type $\left(-0.35 \mathrm{Mg} \mathrm{ha}^{-1}\right)$ was underestimated more than the simulation for the malt type $\left(-0.01 \mathrm{Mg} \mathrm{ha}^{-1}\right)$ (Table 6). However, the values of $M A E$ and $M B E$ were low, indicating that the ALMANAC model was successfully validated.

After ALMANAC was successfully calibrated and validated, the dry grain yields of the naked and malt barley types were simulated for 2001-2018 with three differ- ent decaying rainfall patterns, including prolonged decay, abrupt decay, and symmetrical decay. In comparison with the reference years, spring rainfall amounts during the prolonged and symmetrical decay years increased by $20 \%$ and $40 \%$, respectively. Greater seasonal rainfall tended to decrease the barley grain yields in simulations (Fig. 1 and Table 7). For naked barley, the simulated grain yields during the years of 2001-2018 with the reference rainfall pattern was $3.5 \mathrm{Mg} \mathrm{ha}^{-1}$ while grain yields with prolonged and symmetrical rainfall patterns were 3.42 and $3.12 \mathrm{Mg} \mathrm{ha}^{-1}$, respectively. Like naked barley, malt barley also decreased its grain yields with prolonged and symmetrical rainfall patterns. Although the rainfall amount and grain yields 

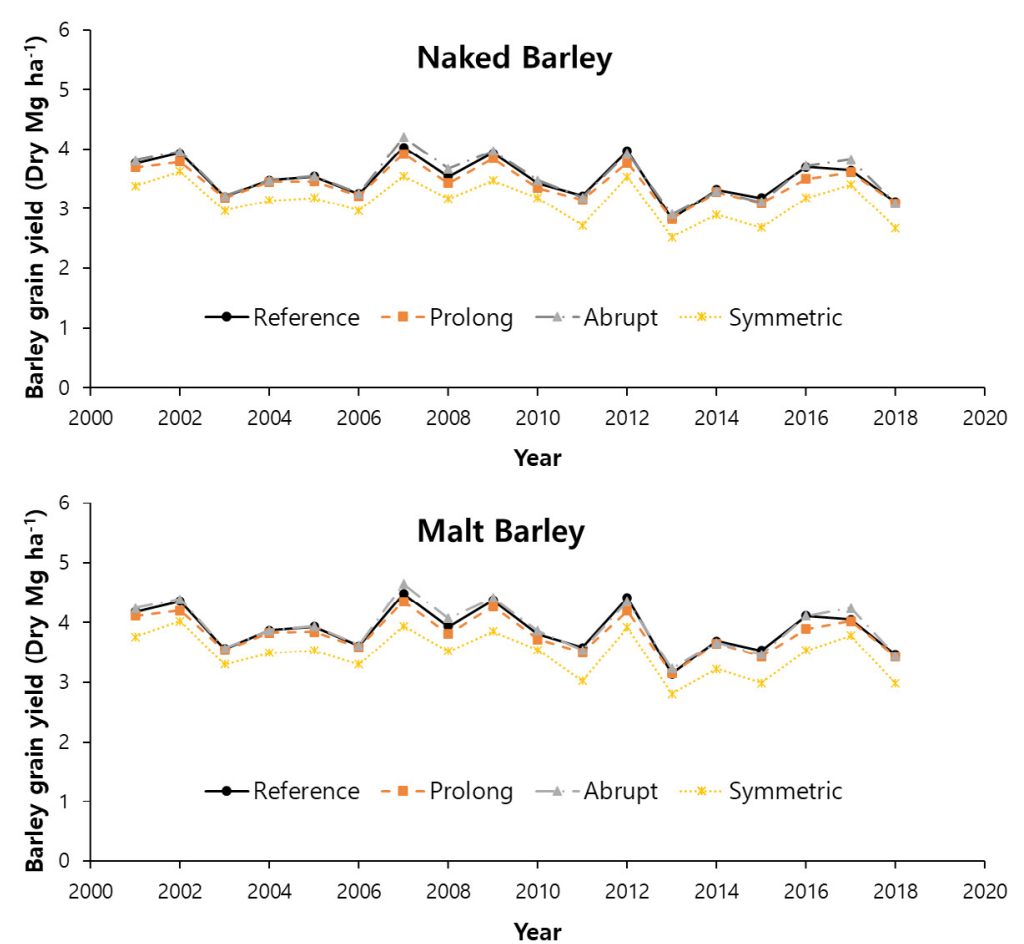

Fig. 1. Comparison of simulated barley grain yields $\left(\mathrm{Mg} \mathrm{ha}^{-1}\right)$ of naked and malt barley types during the years 2001-2018 with reference and three different seasonal rainfall patterns (prolonged decay, abrupt decay, and symmetrical decay). The reference indicates historical rainfall data in 2001-2018. During the prolonged decay years, spring rainfall increased by $20 \%$. During the abrupt decay years, spring rainfall decreased by $10 \%$. During the symmetrical decay years, spring rainfall increased by $40 \%$.

were positively correlated (Table 4), excessive rainfall may decrease the barley grain yield (Table 7). In the simulation, the amount of surface runoff, soil loss, and nutrient loss increased as the amount of rainfall increased (Table 8). The soil and nutrient losses from surface runoff negatively affected the yield production for both barley types. During the abrupt decay years, both the naked and malt barley types slightly increased their yields by $0.3-0.4 \mathrm{Mg}$ $\mathrm{ha}^{-1}$ (Table 7). As compared with the reference, nutrient loss in surface runoff during the abrupt decay years decreased slightly (Table 8), which means that more nutrients were available for plant growth.

The ALMANAC model successfully simulated the yields of two types of barley (naked and malt) under three different seasonal rainfall scenarios. Based on these sim- ulation results, unit sales price (or unit revenue) for the two barley types were estimated using non-linear regression models (Eq. (6) for naked barley and Eq. (7) for malt barley):

$$
\begin{aligned}
& y=2207.5 x^{-0.754} \text { for } 2 \leq x \leq 5, \\
& y=4016.5 x^{-1.148} \text { for } 2 \leq x \leq 5,
\end{aligned}
$$

where: $y$ and $x$ were the price $\left(\$ \mathrm{Mg}^{-1}\right)$ and grain yield $(\mathrm{Mg}$ $\left.\mathrm{ha}^{-1}\right)$, respectively. The $\mathrm{R}^{2}$ values of these two models were 85.0 and $79.7 \%$, respectively. According to Eqs (6) and (7), the price $\left(\$ \mathrm{Mg}^{-1}\right)$ decreased as grain yield increased. Note that both equations were developed based on data collected from the subject area (i.e., Naju-si, Jeollanam-do, South Korea). With regard to the fact that Jeollanam-do produced $44 \%$ of the total barley production in South Korea

Table 7. Dry grain yields $\left(\mathrm{Mg} \mathrm{ha}^{-1}\right)$ and standard deviations of naked and malt barley types and total seasonal rainfall amounts during

\begin{tabular}{|c|c|c|c|c|c|c|}
\hline Barley type & Grain yield & Measured & Simulated & Prolong & Abrupt & Symmetric \\
\hline \multirow{2}{*}{ Naked } & Grain yield & 3.67 & 3.50 & 3.42 & 3.54 & 3.12 \\
\hline & SD & 0.53 & 0.34 & 0.30 & 0.37 & 0.33 \\
\hline \multirow{2}{*}{ Malt } & Grain yield & 3.90 & 3.89 & 3.81 & 3.93 & 3.47 \\
\hline & $\mathrm{SD}$ & 0.70 & 0.38 & 0.34 & 0.41 & 0.37 \\
\hline \multicolumn{2}{|c|}{ Seasonal rainfall (mm) } & 505 & 505 & 606 & 454 & 707 \\
\hline
\end{tabular}
reference years with normal and different seasonal rainfall patterns (prolonged decay, abrupt decay, and symmetric decay)

Reference indicates historical rainfall data in 2001-2018. During prolonged decay years, spring rainfall increased by $20 \%$. During abrupt decay years, spring rainfall decreased by $10 \%$. During symmetric decay years, spring rainfall increased by $40 \%$. 
Table 8. ALMANAC outputs of surface runoff, soil loss, and nutrient loss estimated by simulating naked and malt barley types during years 2001-2018 with reference and different seasonal rainfall patterns (prolong decay, abrupt decay, and symmetric decay)

\begin{tabular}{|c|c|c|c|c|}
\hline \multirow{2}{*}{ Barley type } & \multirow{2}{*}{ Seasonal rainfall pattern } & \multicolumn{3}{|c|}{ Simulation output } \\
\hline & & $\mathrm{Q}(\mathrm{mm})$ & MUSL $\left(\mathrm{Mg} \mathrm{ha}^{-1}\right)$ & $\mathrm{YNO}_{3}\left(\mathrm{~kg} \mathrm{ha}^{-1}\right)$ \\
\hline \multirow{4}{*}{ Naked barley } & Reference & 521.54 & 12.33 & 9.37 \\
\hline & Prolong & 693.99 & 23.18 & 10.75 \\
\hline & Abrupt & 507.69 & 15.39 & 8.55 \\
\hline & Symmetry & 796.2 & 28.13 & 13.11 \\
\hline \multirow{4}{*}{ Malt barley } & Reference & 521.36 & 12.34 & 8.61 \\
\hline & Prolong & 693.81 & 23.07 & 10.19 \\
\hline & Abrupt & 507.51 & 15.35 & 7.93 \\
\hline & Symmetry & 796.02 & 28.12 & 12.47 \\
\hline
\end{tabular}

$\mathrm{Q}$ - surface runoff $(\mathrm{mm})$, MUSL - soil loss from water erosion using modified USLE (MUSLE) $\left(\mathrm{Mg}\right.$ ha $\left.{ }^{-1}\right)$, and $\mathrm{YNO}_{3}-\mathrm{NO}_{3}$ loss in surface runoff $\left(\mathrm{kg} \mathrm{ha}^{-1}\right)$. Other explanations as in Table 7.

Table 9. Estimated price $\left(\$ \mathrm{Mg}^{-1}\right)$ for naked and malt barley types in reference years (measured and simulated) and rainfall scenarios (prolong, abrupt, symmetric scenarios)

\begin{tabular}{llccccc}
\hline Barley type & Estimated price & Measured & Simulated & Prolong & Abrupt & Symmetric \\
\hline \multirow{2}{*}{ Naked } & Price $\left(\$ \mathrm{Mg}^{-1}\right)$ & 828 & 858 & 873 & 851 & 936 \\
& SD & 76 & 106 & 116 & 99 & 108 \\
\multirow{3}{*}{ Malt } & Price $\left(\$ \mathrm{Mg}^{-1}\right)$ & 842 & 844 & 865 & 835 & 963 \\
& SD & 51 & 192 & 219 & 176 & 198 \\
\hline
\end{tabular}

Explanations as in Table 7.

(Statistics Korea, 2020b), the sales prices given by both equations could be influenced by the total demand of barley in South Korea. Barley consumption for both the naked type and malt barley were about 243000 and $64000 \mathrm{Mg}$, respectively (Statistics Korea, 2020a). Demand for barley has remained low mainly due to a decreasing demand for rice substitutes in the Korean market (USDA-FAS, 2019). If there is an overproduction of barley, it will cause a significant drop in the barley price. This may reduce profits for farmers. Eqs (6) and (7) were used to estimate the prices of two types of barley from Table 7 . The results are shown in Table 9.

The total harvested areas of naked barley and malt barley in 2000-2018 were about 21500 ha and 16600 ha in South Korea, respectively (Statistics Korea, 2020a). The total harvested area for each barley type was used to estimate the total barley production and its annual revenue under three rainfall scenarios (Table 10). The estimated unit prices from Eqs (6) and (7) are multiplied by the annual harvested yields for the estimation of the annual revenue. For naked barley, the abrupt scenario had the highest annual revenue, although it had the lowest unit price $\left(\$ 851 \mathrm{Mg}^{-1}\right)$ among the three scenarios (Table 9). Obviously, its production quantity $(76114 \mathrm{Mg})$ was much higher than those of the other two scenarios (i.e., $73500 \mathrm{Mg}$ for prolonged and $67100 \mathrm{Mg}$ for symmetrical decay). Thus, the abrupt scenario produced the highest revenue. However, different results were obtained for the malt barley. The symmetrical scenario produced the highest revenue, although it had the lowest yield of $57486 \mathrm{Mg}$. Unlike the three scenarios for naked barley, overproduction caused a significant drop in unit price. Although yields for the abrupt scenario and the prolonged scenario were 65106 and $63118 \mathrm{Mg}$, respectively, they could only make $\$ 54588647$ and $\$ 54338686$, respectively. Obviously, the unit price of the malt barley was much more sensitive to production yield than that of the naked barley (Eqs (6) and (7)).

The simulation results were presented in terms of potential losses of soil and nutrients from farm fields and potential soil quality degradation under higher rainfall events, which lead to drops in the potential agricultural productivities of both naked and malt barley types. Changes in crop yields were expected to affect barley production and prices. For the naked barley type, the revenue increased as its yield increased. Unlike naked barley types, the malt barley type showed a drop-in revenue when its production increased. According to this simulation result, planting malt barley types under higher rainfall conditions could be more attractive to farmers than the naked types due to higher economic benefits. However, despite malt types producing higher economic benefits under extreme weather events, the naked type had more stability in terms of production and price. 
Table 10. Estimated annual revenue for naked and malt barley types in reference years (measured and simulated) and three rainfall scenarios (prolong, abrupt, symmetric scenarios)

\begin{tabular}{llrrrrr}
\hline \multirow{2}{*}{ Barley type } & $\begin{array}{l}\text { Estimated } \\
\text { annual revenue }\end{array}$ & Measured & Simulated & Prolong & Abrupt & Symmetric \\
\hline \multirow{2}{*}{ Naked } & Revenue (\$) & 65354055 & 64595970 & 64229584 & 64776800 & 62795239 \\
& SD & 21302 & 29072 & 31582 & 27432 & 28074 \\
\multirow{2}{*}{ Malt } & Revenue (\$) & 54400346 & 54421021 & 54588647 & 54338686 & 55349087 \\
& SD & 24260 & 48857 & 54937 & 45005 & 47578 \\
\hline
\end{tabular}

Explanations as in Table 7.

According to Table 7 , the standard deviation of the naked types in three scenarios are lower than those of malt barley. Similarly, in Tables 9 and 10, the naked types had a lower standard deviation than the malt barley in each scenario. This implies that the naked barley is more stable in terms of production and price. Since the naked type is known as a healthy food in South Korea, it is consistently consumed by Koreans who care about their health (Baik and Ullrich, 2008; Choi et al., 2010; Lee et al., 2013). Moreover, it has been a popular crop as a rice substitute and ingredient of a traditional Korean drink (Newman and Newman, 2006). On the other hand, this particular malt type is used to produce Korean beer which is under excessive competition from imported beer. Koreans have started to drink imported beer so that sales of domestic beer brewed using the abovementioned malt type have changed suddenly resulting from the marketing strategies of beer sellers (Lee and Cho, 2016; Yi et al., 2016). Therefore, in comparison with the malt type, the naked type is the more attractive type to farmers in terms of stability. However, in order to determine if this theory is reliable, it is essential to validate model outcomes with data observed from a field experiment that estimates yield changes under different rainfall events.

\section{CONCLUSIONS}

1. The accurate forecasting of barley yield is a critical step towards meeting the future demand for this crop. In this study, a process-based model, Agricultural Land Management Alternatives with Numerical Assessment Criteria was used to simulate two barley types, naked and malt, in a temperate region. Most of Korea's barley is grown in a temperate environment. Thus, modelling barley yield in this region will help to determine a realistic future for barley production in Korea. The crop model was developed based on 19 years of field data. The model was calibrated and validated using yield data from 2001-2009 and 20102018, respectively. As a result, the Agricultural Land Management Alternatives with Numerical Assessment Criteria model could predict grain yield very well for both barley types.

2. The validated Agricultural Land Management Alternatives with Numerical Assessment Criteria was used to quantify extreme rainfall impacts on barley yields. Three extreme rainfall scenarios, prolong $(+20 \%$ seasonal rainfall), abrupt $(-10 \%)$, and symmetrical $(+40 \%)$ decaying rainfall patterns, were simulated. The barley tended to decrease its yield as rainfall increased. This might be because heavy rainfall generated soil and nutrient losses through surface runoff, resulting in yield loss.

3. The annual revenue and unit prices for barley types were analysed based on yield estimations under different rainfall scenarios. Two non-linear models for naked and malt barley were established via non-linear models at $\alpha=0.05$ with $\mathrm{R}^{2}$ values of 85.0 and $79.7 \%$, respectively. Both models revealed that the revenue patterns for naked and malt barley differed in terms of rainfall scenarios. For the malted barley type, the barley price increased as grain yield decreased.

4. In economics, "scarcity" occurs when an item becomes attractive but has restricted availability. As a result, the highest revenue of malt barley type was observed during symmetrical decaying years. On other hand, overproduction of the naked barley type caused its unit price to drop significantly. The naked barley type produced the highest annual revenue during the abrupt decaying years among other scenarios. This also showed that the scarcity of naked barley affects the annual revenue. These simulation results suggest that seasonal rainfall changes may significantly affect barley yield as well as its food price at $\alpha=0.05$ with reliable $\mathrm{R}^{2}$ values higher than $79 \%$.

5. This finding will provide farmers with important information concerning the impacts of extreme weather events on barley yield, which could make barley adapt better and perform well under abiotic stressful conditions.

Conflict of interest: The authors declare no conflict of interest.

\section{REFERENCES}

Baik B.K., Newman C.W., and Newman R.K., 2011. In Barley: Production, Improvement, and Uses. (Ed. S.E. Ullrich). WileyBlackwell, Oxford, UK.

Baik B.K. and Ullrich S.E., 2008. Barley for food: characteristics, improvement, and renewed interest. J. Cereal Sci., 48(2), 233-242. https://doi.org/10.1016/j.jcs.2008.02.002

Barboza G., Gavinelli L., Pede V., Mazzucchelli A., and Di Gregorio A., 2020. A contribution to the empirics of food price behavior: the case of rice price dynamics in Italy. BFJ 2020, https://doi.org/10.1108/bfj-12-2019-0937 
Behrman K.D., Keitt T.H., and Kiniry J.R., 2014. Modeling differential growth in switchgrass cultivars across the Central and Southern Great Plains. BioEnergy Res., 7, 1165-1173. https://doi.org/10.1007/s12155-014-9450-8

Cammarano D., Ceccarelli S., Grando S., Romagosa I., Benbelkacem A., Akar T., Al-Yassin A., Pecchioni N., Francia E., and Ronga D., 2019. The impact of climate change on barley yield in the Mediterranean basin. Eur. J. Agron., 106, 1-11.https://doi.org/10.1016/j.eja.2019.03.002

Carter C.A., 1994. The economics of a single North American barley market: A reply. CJAE, 42, 413-419.

Choi J.S., Kim H., Jung M.H., Hong S., and Song J., 2010. Consumption of barley $\beta$-glucan ameliorates fatty liver and insulin resistance in mice fed a high-fat diet. Mol. Nutr. Food Res., 54(7), 1004-1013. https://doi.org/10.1002/mnfr.200900127

Debaeke P., Caussanel J.P., Kiniry J.R., Kafiz B., and Mondragon G., 1997. Modelling crop:weed interactions in wheat with ALMANAC. Weed Res., 37, 325-341. https:// doi.org/10.1046/j.1365-3180.1997.d01-55.x

Druille M., Williams A.S., Torrecillas M., Kim S., Meki N., and Kiniry J.R., 2020. Modeling climate warning impacts on grain and forage sorghum yields in Argentina. Agronomy, 10, 964. https://doi.org/10.3390/agronomy 10070964

Eissa M.A. and Al Refai H., 2019. Modelling the symmetric and asymmetric relationships between oil prices and those of corn, barley, and rapeseed oil. Resour. Policy, 64, 101511. https://doi.org/10.1016/j.resourpol.2019.101511

FAO, Food and Agriculture Organization of United Nations, 2020. FAOSTAT. FAO Rome, Italy. Available online: http:// www.fao.org/faostat/en/\#data/QC (Accessed on October 10th 2020). https://doi.org/10.1787/1112c23b-en

Grassini P., van Bussel L.G.J., Wart J.V., Wolf J., Classens L., Yang H., Boogaard H., de Groot H., van Ittersum M.K., and Cassman K.G., 2015. How good is good enough? Data requirements for reliable crop yield simulations and yield-gap analysis. Field Crops Res., 177, 49-63. https:// doi.org/10.1016/j.fcr.2015.03.004

Khush G.S., 1987. Rice breeding: past, present and future. J. Genetics, 66, 195-216. https://doi.org/10.1007/bf02927713

Kim J.S., Son C.Y., Moon Y.I., and Lee J.H., 2017. Seasonal rainfall variability in Korea within the context of different evolution patterns of the central Pacific El Nino. J. Water Clim. Change, 8, 412-422.

https://doi.org/10.2166/wcc.2016.020

Kim S., Kim S., Cho J., Park S., Jarrín Perez F. X., and Kiniry J.R., 2020. Simulated biomass, climate change impacts, and nitrogen management to achieve switchgrass biofuel production at diverse sites in US. Agronomy, 10(4), 503. https://doi.org/10.3390/agronomy10040503

Kim S., Kiniry J.R., Williams A.S., Meki N., Gaston L., Brakie M., Shadow A., Fritschi F.B., and Wu Y., 2017. Adaptation of $\mathrm{C} 4$ bioenergy crop species to various environments within the southern great plains of USA. Sustainability, 9, 89. https://doi.org/10.3390/su9010089

Kiniry J.R., Major D.J., Izaurralde R.C., Williams J.R., Gassman P.W., Morrison M., Bergentine R., and Zentner R.P., 1995. EPIC model parameters for cereal, oilseed, and forage crops in the northern Great Plains region. Can. J. Plant Sci., 75, 679-688. https://doi.org/10.4141/cjps95-114

KMA (Korea Meteorological Administration), 2014. Korean
Climate Change Assessment Report 2014: Climate Change Impacts and Adaptation. Incheon, Republic of Korea: National Institute of Environmental Research.

KMA, Korea Meteorological Administration, 2020. Weather pattern in Korea. http://www.kma.go.kr/notify/press/kma_list. jsp?bid $=$ press\&mode $=$ view\&num $=1193858$. (accessed on September 8th 2020).

Ko J., Ng C.T., Jeong S., Kim J.H., Lee B., and Kim H.Y., 2019. Impacts of regional climate change on barley yield and its geographical variation in South Korea. Int. Agrophys., 33, 81-96. https://doi.org/10.31545/intagr/104398

Lee H. and Cho S., 2016. Hitejinro Sustaining Success in the Korean Beer Market. IJBMR, 6(3),11-22.

Lee M., Kim K., Kim Y., Choi J., Park K., and Kim H., 2013. Quality characteristics and antioxidant activity of noodle containing whole flour of Korean hull-less barley cultivars. Korean J. Crop Sci., 58(4), 459-467. https://doi.org/10.7740/ kjcs.2013.58.4.459

Monsi M. and Saeki T., 1953. Uber Den Lichtfaktor in Den Pflanzen-Gesellschaften Und Seine Bedeutung Fur DieSto produktion. Jpn. J. Bot., 14, 22-52.

Munns R. and Tester M., 2008. Mechanisms of salinity tolerance. Ann. Rev. Plant Biol., 59, 651-681. https://doi.org/10.1146/annurev.arplant.59.032607.092911

Naju-si, 2020. Naju agriculture. http:/www.naju.go.kr/atec/naju. (accessed on November 12th, 2020). https://doi.org/10.25232/ku.2020.54.273

Nevo E., Fu Y.B., Pavlicek T., Khalifa S., Tavasi M., and Beiles A., 2012. Evolution of wild cereals during 28 years of global warming in Israel. PNAS, 109, 3412-3415. https://doi. org/10.1073/pnas. 1121411109

Newman C.W. and Newman R.K., 2006. A brief history of barley foods. Cereal Foods World, 51(1), 4-7. https://doi.org/10.1094/cfw-51-0004

Newton A.C., Flavell A.J., George T.S. et al., 2011. Crops that feed the world 4. Barley: a resilient crop? Strengths and weaknesses in the context of food security. Food Sec., 3, 141. https://doi.org/10.1007/s12571-011-0126-3

Statistics Korea, 2020a. KOSIS: Production of Barley. http:// kostat.go.kr/portal/korea/index.action (accessed on Oct. 11th 2020).

Statistics Korea, 2020b. Production of barley, garlic, and onions in 2020. Online available at file://C:/Users/ksumi/ Downloads/pbgo2020.pdf (accessed on November 12th, 2020).

Takác Ĵ. and Šiška B., 2009. Climate change impact on spring barley and winter wheat yields on Danubian Lowland. In: Bioclimatology and Natural Hazards (Eds K. Střelcová et al.). Springer, Dordrecht, 283-288. https://doi.org/10.1007/978-1-4020-8876-6_24

USDA-FAS, USDA Foreign Agricultural Service, 2019. Barley market brief in Korea. https://apps.fas.usda.gov/newgainapi/api/report/downloadreportbyfilename?filename=Barl ey $\% 20$ Market $\% 20$ Brief\%20in\%20Korea_Seoul_ Korea\%20-\%20Republic\%20of_4-2-2019.pdf (accessed on September 8th 2019).

Yi Y.S., Kang H.G., and Jun H., 2016. Build to last, discount, or defer?: Examining lotte's entry into the beer industry. Asian Case Res. J., 20(02), 429-454. https://doi.org/10.1142/s0218927516500164 